\title{
GPC6 wt Allele
}

National Cancer Institute

\section{Source}

National Cancer Institute. GPC6 wt Allele. NCI Thesaurus. Code C101405.

Human GPC6 wild-type allele is located in the vicinity of $13 q 32$ and is approximately 1181

$\mathrm{kb}$ in length. This allele, which encodes glypican- 6 protein, is involved in cell-protein interactions. Mutation of the gene is associated with omodysplasia type 1. 